\title{
The Relationship between the Anteroposterior Diameter of the Patellar Tendon, Pain and Functionality in Volleyball Players - An Observational Study
}

\section{Relación entre diámetro antero-posterior del tendón rotuliano, dolor y funcionalidad en jugadores de voleibol - estudio observacional}

\author{
Alfonso Calvo Gonell ${ }^{1}$ Loreto Macia Soler ${ }^{2}$ Joaquin Moncho ${ }^{3}$ \\ ${ }^{1}$ Centro de Fisioterapia Alfonso Calvo, Castellón, Spain \\ 2 Department of Nursing, Faculty of Health Science, Universidad de \\ Alicante, Alicante, Spain \\ ${ }^{3}$ Department of Community Nursing, Preventive Medicine and Public \\ Health and History of Science, Universidad de Alicante, Alicante, Spain

\begin{abstract}
Address for correspondence Alfonso Calvo Gonell, Centro de Fisioterapia Alfonso Calvo, C/ Santa María Rosa Molas, $401^{\circ}$-D3, 12004 Castellón, Spain (e-mail: alfonscalvo@hotmail.com; info@fisioterapiaalfonsocalvo.es).
\end{abstract} \\ Rev Fisioter Invasiva 2019;2:18-28.
}

\begin{abstract}
Keywords

- volleyball

- patellar tendon

- sports injuries
\end{abstract}

Resumen
Objective To determine whether the anteroposterior (AP) diameter of the patellar tendon in volleyball players is associated with a greater sensation of pain and decreased functionality.

Material and Methods A descriptive, observational, cross-sectional study conducted on volleyball players. The scores on the Victorian Institute of Sport Assessment-Patella (VISA-P) scale were registered, together with the visual analogue scale (VAS) and the AP diameter of the patellar tendon, at 5 and at $10 \mathrm{~mm}$ distal to the inferior pole of the patella. The demographic, anthropometric and playing characteristics were registered and multiple linear regression models were constructed in order to analyze the relationship between the study variables.

Results The final sample comprised 112 players. The AP diameter was greater in men and showed a positive significant association with the score on the VAS scale and a negative significant association with the VISA-P for both tendons after adjusting for the remaining variables.

Conclusions The measurement of the AP diameter of the patellar tendon may be useful for the prevention of sports injuries in volleyball players as a greater tendon diameter is significantly associated with increased perceived pain and decreased functionality. Future studies should include a biomechanical analysis of jump and reception techniques.

Objetivos Determinar si el diámetro antero-posterior del tendón rotuliano en jugadores de voleibol está asociado a una mayor sensación de dolor y menor funcionalidad.

Material y Métodos Estudio observacional descriptivo transversal realizado sobre jugadores/as de voleibol. Se registraron las puntuaciones de la escala VISA-P, la escala analógica visual (EVA) y el diámetro antero-posterior del tendón rotuliano a 5 y $10 \mathrm{~mm}$
DOI https://doi.org/ 10.1055/s-0039-1685232. ISSN 2386-4591.
Copyright $\odot 2019$ by Thieme Revinter Publicações Ltda, Rio de Janeiro, Brazil
License terms

(c) (1) $\ominus$ (\$) 
Palabras clave

- voleibol

- tendón rotuliano

- lesiones deportivas del polo inferior de la rótula distalmente. Se registraron características demográficas, antropométricas y del juego y se construyeron modelos de regresión lineal múltiple para analizar la relación entre las variables de estudio.

Resultados La muestra final fue de 112 jugadores. El diámetro antero-posterior fue mayor en hombres y se asoció significativamente con las puntuaciones de la escala EVA positivamente y VISA-P de manera negativa para ambos tendones una vez ajustados por el resto de variables.

Conclusiones La determinación del diámetro antero-posterior del tendón rotuliano puede ser útil en la prevención de lesiones deportivas en jugadores de voleibol, al asociarse significativamente un mayor diámetro de éste con una mayor sensación de dolor y menor funcionalidad. Sería conveniente en futuros estudios incluir un análisis biomecánico de la técnica del salto y recepción.

\section{Introduction}

Volleyball is the sport with the greatest prevalence of patellar tendinopathy, with an incidence of $44.6 \%$, followed by basketball, with an incidence of $31.9 \%$. $^{1}$ Some studies show that there is a greater prevalence of this pathology among men in comparison to women. ${ }^{1,2}$ The risk factors include a greater jump capacity, starting to train at a younger age, taller players, and those with a higher body weight. ${ }^{1,3,4}$ Other studies indicate that there is a direct relationship between training volume and the prevalence of this pathology in volleyball. ${ }^{5}$ In a study by Cassel et al, ${ }^{6}$ the subjects with patellar tendinopathy were older, taller, weighed more, trained more hours per week and had a higher tendon thickness. Furthermore, according to Schafle et al, ${ }^{7}$ players at the net have three times more knee injuries compared with those who play in the defense line. Also, a study by Lian ${ }^{1}$ concluded that the hours of volleyball training and strength training are associated with a greater probability of injuring the patellar tendon.

Most injuries related to the practice of this sport occur during an attack and a block, as this is where jumps are more compromised. Overuse injuries in this sport represent between 50 and $80 \%$ of the total, of which $80 \%$ are patellar tendinopathies. ${ }^{8}$ It seems that the high-load demands, the performance of the sports gesture, stress upon the extensor apparatus of the knee, and a lack of recovery time are all factors that can lead to chronic injuries to the patellar tendon. ${ }^{9-11}$

Ultrasound (US) can be used to obtain an image of the patellar tendon, by obtaining images both in longitudinal and transverse scans. ${ }^{12}$ Tendons can be well visualized sonographically, as they have a greater density of collagen, meaning that they can be distinguished from the surrounding tissues and are easily visualized by the latest high frequency transducers. ${ }^{13}$ The width of the tendon bears a direct relationship with the finding of abnormal and diffuse images with accumulation of ground substance and affecting both genders, although this is less pronounced among women. ${ }^{6,14}$ According to a study by Malliaras et $\mathrm{al}^{14}$ on Australian volleyball players, an anteroposterior (AP) diameter $>4 \mathrm{~mm}$ in women and $>4.2 \mathrm{~mm}$ in men was found to be a predictive factor of patellar tendinopathy. The same authors affirmed that tendons with abnormal images, in other words, with a fibrillar pattern, were almost $44 \%$ thicker than normal, while tendons with anechoic foci were $82 \%$ thicker than the rest. Visnes et $\mathrm{a}^{15}$ also studied volleyball players and found that having a patellar tendon diameter $>5 \mathrm{~mm}$ in men and $>4.2$ $\mathrm{mm}$ in women was associated with a greater probability of suffering from patellar tendinopathy. According to several authors, ${ }^{16,17}$ this increased diameter is often associated with greater pain in athletes with tendinopathy. Zhang et $\mathrm{al}^{16}$ also considered that painful tendons were, on average, 33\% thicker than the rest. However, Kulig et $\mathrm{al}^{18}$ affirmed that the measurement of the tendon diameter alone was not enough to diagnose the pathology, but rather the tendon morphology should be analyzed together with the organization of the bundles.

Whereas the aforementioned studies were focused on researching whether the use of US alone was sufficient for enabling the diagnosis of patellar tendinopathy, the aim of the present study was to determine whether the AP diameter of the patellar tendon in volleyball players is associated with a greater sensation of pain, according to the visual analogue scale (VAS) and decreased functionality, according to the Victorian Institute of Sport Assessment-Patella (VISA-P) scale.

\section{Material and Methods}

A descriptive cross-sectional observational study performed with volleyball players competing in the three main categories in Spain.

The study population comprised volleyball players aged between 18 and 38 years old who played in the senior male and senior female categories within the Spanish Super League, the Super League 2, and the Spanish First Division. The selected sample included 112 volleyball players from 9 teams who competed in different categories during the 2016-2017 season and who fulfilled the inclusion/exclusion criteria.

The inclusion criteria were: 1 ) being $>18$ years old; 2 ) accepting to participate in the study, and 3) actively training at the time of data collection. The exclusion criteria were: 1 ) 
The Relationship between the Anteroposterior Diameter of the Patellar Tendon, Pain and Functionality in Volleyball

being $<18$ years old; 2 ) suffering from some type of injury preventing them from participating in training sessions as usual; 3) receiving a surgical intervention on the knee at some point in their career, with the exception of interventions performed via arthroscopy; 4) having been under treatment with corticosteroids orally, topically or parenterally during the previous 3 months; 5) suffering diabetes or suffering from some type of inflammatory systemic disease; 6) using some type of insole support for sports practice or having suffered immobilization of the ankle due to any kind of injury during the previous 3 months.

All of the subjects who participated in the present study were duly informed of the aim of the study, ensuring their comprehension, and they voluntarily signed the informed consent during the recruitment period. The subjects were anonymously identified with a number. The data were treated confidentially and were registered and safeguarded in files which were only accessible by the researcher, according to the principles of the Declaration of Helsinki.

The outcome measures used were the VISA-P, the VAS, and the AP diameter of the patellar tendon, measured at $5 \mathrm{~mm}$ and at $10 \mathrm{~mm}$ distal to the inferior pole of the patella. Additionally, the following variables were registered: gender, age, weight, height, body mass index (BMI), number of years playing volleyball, position occupied in the court (middle blocker, center, opposite hitter, libero, and outside hitter), the category in which the player competed (Super League, Super League 2, and First Division), number of years with knee pain, number of hours of training per week (for both strength training and for volleyball), and type of court where training was most often performed (Taraflex [Gerflor, Villeurbane, France), wood, cement).

The data collection took place during the months of September and October 2016, on behalf of two researchers who visited the study site. A questionnaire was completed (-Annex 1) and a personal interview was performed with each participant in order to verify the inclusion/exclusion criteria.

Subsequently, the Spanish version of the Victorian Institute of Sport Assessment-Patella (VISA-P-SP) ${ }^{19}$ questionnaire and the VAS were evaluated during training sessions. The participants registered their level of pain at the patellar tendon during volleyball training sessions. Finally, a sonographic analysis of both tendons was performed. A grayscale program was standardized with the same parameters for all of the subjects with a gray map protocol of $\mathrm{A} / 0$, a $40 \mathrm{db}$ gain, a frequency of $12 \mathrm{~Hz}$, a depth of 4.0, two sites, harmonic imaging and crossBeam technology. All of the subjects were examined using a Logiq-e R6 ultrasound (General Electric, Chicago, IL, USA) equipped with a linear 12L-RS probe. Furthermore, an Aquasonic 100 transmission gel (Parker laboratories, Fairfield, NJ, USA) was applied at room temperature to facilitate the contact between the probe and the skin.

The width of the tendon was measured in the longitudinal plane both at $5 \mathrm{~mm}^{20}$ and at $10 \mathrm{~mm}^{21}$ distal from the inferior pole of the patella following the criteria by Cook et al, ${ }^{20}$ by Black et $a l^{21}$ and by Skou et al, ${ }^{22}$ due both to its reliabili$t y^{21,22}$ as well as to the fact that this is the area where

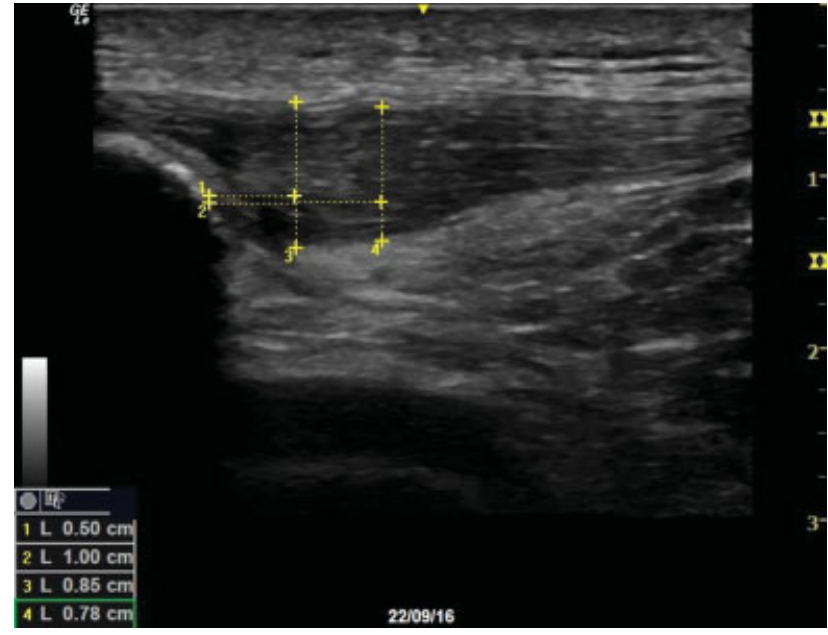

Fig. 1 Two measurements: at $5 \mathrm{~mm}$ and at $10 \mathrm{~mm}$ distally from the inferior pole of the patella and the anteroposterior mean from the deep fascicle of the patellar tendon between the superficial fascicle and the subcutaneous tissue.

symptoms are frequently located. ${ }^{21,22}$ The measurement was performed directly using the ultrasound device by tracing a $5 \mathrm{~mm}$ line continued by another line $5 \mathrm{~mm}$ from the inferior pole of the patella. This created a perpendicular line to the end of each of the lines which went from the deepest area of the deep tendon fascicle to the interphase between the most superficial part of the superficial fascicle and the subcutaneous cell tissue ( $\mathbf{- F i g . 1} \mathbf{1}$ ).

A descriptive analysis of the study variables was performed using the PASW Statistics for Windows, Version 18.0 (SPSS Inc., Chicago, IL, USA). Frequencies and percentages were calculated for the qualitative variables together with the means, standard deviations (SDs) and corresponding 95\% confidence intervals (CIs) for the quantitative variables. For the analysis of possible associations between the qualitative variables, either the chi-squared test or the exact Fisher test was used according to the conditions of application. However, for the quantitative variables, the Pearson correlation coefficient and/or the Spearman rank-order correlation was calculated, and the corresponding linear regression models were constructed to determine the nature of the relation and of the magnitude of the effects. Finally, multiple linear regression models were constructed in order to adjust the effect of the remaining variables. Considering that the AP diameter of the patellar tendon at $5 \mathrm{~mm}$ and at $10 \mathrm{~mm}$ showed an elevated linear correlation, the multivariate models were adjusted using both measurements separately.

\section{Results}

The initial sample comprised 125 subjects, of which 10 were excluded because they used some type of insole support for the insole, and 3 were excluded as they had a type of lower limb injury at the time of the study. Therefore, the final sample consisted of 112 subjects.

Out of the 112 subjects analyzed, 71 were men (63.4\%) and 41 were women (36.6\%). The mean age of the subjects was 
Table 1 Sociodemographic data of the subjects

\begin{tabular}{|l|l|l|l|l|l|l|}
\hline & \multicolumn{3}{l}{ Both genders } & \multicolumn{2}{l|}{ Men } & Women \\
\hline & Mean \pm SD & $95 \% \mathrm{Cl}$ & Mean \pm SD & $95 \% \mathrm{Cl}$ & Mean \pm SD & 95\% CI \\
\hline Age & $24.18 \pm 5.85$ & $23.08-25.27$ & $24.31 \pm 5.18$ & $23.16-25.47$ & $24.48 \pm 7.37$ & $22.29-26.67$ \\
\hline Height & $1.83 \pm 0.11$ & $1.81-1.85$ & $1.89 \pm 0.08$ & $1.87-1.90$ & $1.73 \pm 0.07$ & $1.71-1.76$ \\
\hline Weight & $76.72 \pm 12.39$ & $74.40-79.04$ & $83.58 \pm 8.76$ & $81.63-85.53$ & $64.79 \pm 7.63$ & $62.53-67.06$ \\
\hline BMI & $22.83 \pm 2.16$ & $22.43-23.23$ & $23.48 \pm 1.82$ & $23.08-23.89$ & $21.55 \pm 1.96$ & $20.97-22.13$ \\
\hline Years playing & $12.18 \pm 6.02$ & $11.05-13.31$ & $12.28 \pm 5.25$ & $11.11-13.44$ & $12.83 \pm 7.26$ & $10.67-14.98$ \\
\hline Hours strength & $3.28 \pm 1.89$ & $2.92-3.63$ & $3.83 \pm 1.93$ & $3.40-4.25$ & $2.20 \pm 1.16$ & $1.85-2.54$ \\
\hline Hours volleyball & $9.83 \pm 7.46$ & $8.43-11.22$ & $12.54 \pm 9.42$ & $10.44-14.63$ & $6.35 \pm 2.03$ & $5.75-6.95$ \\
\hline Pain R knee & $1.14 \pm 2.56$ & $0.65-1.62$ & $2.03 \pm 3.50$ & $1.25-2.82$ & $0.44 \pm 1.94$ & $-0.13-1.02$ \\
\hline Pain L knee & $1.27 \pm 2.85$ & $0.74-1.81$ & $2.06 \pm 3.77$ & $1.22-2.90$ & $0.87 \pm 2.45$ & $0.14-1.60$ \\
\hline
\end{tabular}

Abbreviations: BMI, body mass index; Cl, Confidence interval; L, left; R, right; SD, Standard deviation.

$24.18 \pm 5.8$ years old. The mean years playing volleyball was $12.2 \pm 6$ years, of which, players reported feeling pain in the right and left legs for 1.1 and 1.3 years, respectively (-Table 1).

A total of $38.4 \%$ of the subjects played in the Super League, $27.7 \%$ played in Super League 2, whereas $33.9 \%$ did so in the First Division. Significant differences were found by gender, with men concentrated mainly in the superior leagues, whereas women were in the lower category leagues. The position of volleyball players on the court comprises five possibilities: middle blocker, center, opposite hitter, libero, and outside hitter. In the subjects under study, $11.6 \%$ were middle blockers, $27.7 \%$ were centers, $10.7 \%$ were opposite hitters, $15.2 \%$ were liberos, and $34.8 \%$ were outside hitters. No differences were found in relation to the gender of the players. Concerning the court surface, three types of court surface were studied: Taraflex, wood and cement. Most subjects played on a Taraflex or on a cement surface, while only $9.8 \%$ played on a wooden surface. Significant differences were detected by gender regarding the play surface, therefore, $47.9 \%$ of men played on cement, whereas in women, this percentage was $31.7 \%$, with Taraflex being most common (68.3\%). No female team played on a wooden surface ( - Table 2 ).

- Table 3 displays the average and SDs of the scores on the VAS, on the VISA-P scale, and the AP diameter measurement, both for the left knee and for the right knee, separated by gender. Men complained of more pain than women in both knees, although the difference was only significant for the right knee $(p<0.05)$. Likewise, men registered scores on the VISA-P scale that were lower than those of women, with this difference only being significant for the right knee $(p<0.05)$. Regarding the AP diameter of the tendon at $5 \mathrm{~mm}$ and at $10 \mathrm{~mm}$ distal from the inferior pole of the patella, the mean diameter was significantly greater in men than in women, both for the right knee and for the left knees.

The VAS score was significantly and positively associated $(p<0.05)$ with the right knee, with gender (greater score in men), with the jumping leg (greater in those that jumped with the right knee or both), and with the AP diameter, both at $5 \mathrm{~mm}$ and at $10 \mathrm{~mm}$ (greater scores had a greater AP
Table 2 Variables related with sports activities

\begin{tabular}{|c|c|c|c|c|c|c|c|}
\hline & \multicolumn{2}{|c|}{$\begin{array}{l}\text { Both } \\
\text { genders }\end{array}$} & \multicolumn{2}{|c|}{ Men } & \multicolumn{2}{|c|}{ Women } & \multirow[t]{2}{*}{$p$-value } \\
\hline & $n$ & $\%$ & $n$ & $\%$ & $n$ & $\%$ & \\
\hline \multicolumn{7}{|c|}{ Player position } & 0.978 \\
\hline $\begin{array}{l}\text { Middle } \\
\text { blocker }\end{array}$ & 13 & 11.6 & 9 & $12.7 \%$ & 4 & $9.8 \%$ & \\
\hline Center & 31 & 27.7 & 20 & $28.2 \%$ & 11 & $26.8 \%$ & \\
\hline $\begin{array}{l}\text { Opposite } \\
\text { hitter }\end{array}$ & 12 & 10.7 & 8 & $11.3 \%$ & 4 & $9.8 \%$ & \\
\hline Libero & 17 & 15.2 & 10 & $14.1 \%$ & 7 & $17.1 \%$ & \\
\hline $\begin{array}{l}\text { Outside } \\
\text { hitter }\end{array}$ & 39 & 34.8 & 24 & $33.8 \%$ & 15 & $36.6 \%$ & \\
\hline \multicolumn{7}{|c|}{ Jumping leg } & 0.067 \\
\hline Right & 14 & 12.5 & 9 & $12.9 \%$ & 5 & $12.2 \%$ & \\
\hline Left & 61 & 54.5 & 33 & $47.1 \%$ & 28 & $68.3 \%$ & \\
\hline Both & 36 & 32.1 & 28 & $40.0 \%$ & 8 & $19.5 \%$ & \\
\hline $\begin{array}{l}\text { Not } \\
\text { specified }\end{array}$ & 1 & 0.9 & & & & & \\
\hline \multicolumn{7}{|c|}{ Type of court } & 0.001 \\
\hline Taraflex & 54 & 48.2 & 26 & $36.6 \%$ & 28 & $68.3 \%$ & \\
\hline Wood & 11 & 9.8 & 11 & $15.5 \%$ & 0 & $0.0 \%$ & \\
\hline Cement & 47 & 42.0 & 34 & $47.9 \%$ & 13 & $31.7 \%$ & \\
\hline \multicolumn{7}{|l|}{ Category } & $<0.001$ \\
\hline $\begin{array}{l}\text { Super } \\
\text { league }\end{array}$ & 43 & 38.4 & 43 & $60.6 \%$ & 0 & $0.0 \%$ & \\
\hline $\begin{array}{l}\text { Super } \\
\text { league } 2\end{array}$ & 31 & 27.7 & 18 & $25.4 \%$ & 13 & $31.7 \%$ & \\
\hline $\begin{array}{l}\text { First } \\
\text { division }\end{array}$ & 38 & 33.9 & 10 & $14.1 \%$ & 28 & $68.3 \%$ & \\
\hline
\end{tabular}

diameter). When adjusting the effects via a linear regression model, only the jumping leg and the AP diameter at $5 \mathrm{~mm}$ and at $10 \mathrm{~mm}$ maintained statistical significance for both models, for which it would be necessary to add the number of years playing volleyball in the case of the constructed model, based on the AP diameter at $10 \mathrm{~mm}$. It is possible to observe 
The Relationship between the Anteroposterior Diameter of the Patellar Tendon, Pain and Functionality in Volleyball 22 Players Calvo Gonell et al.

Table 3 Mean score of the VAS and VISA-P scales and total anteroposterior diameter of the patellar tendon and by gender

\begin{tabular}{|l|l|l|l|l|l|l|l|}
\hline \multicolumn{2}{|l}{} & \multicolumn{2}{l}{$\begin{array}{l}\text { Total } \\
n=112\end{array}$} & \multicolumn{2}{l|}{$\begin{array}{l}\text { Men } \\
n=71\end{array}$} & $\begin{array}{l}\text { Women } \\
n=41\end{array}$ & -value \\
& Mean \pm SD & $95 \% \mathrm{Cl}$ & Mean \pm Des & $95 \% \mathrm{Cl}$ & Mean \pm Des & $95 \% \mathrm{Cl}$ & \\
\hline VAS R & $1.78 \pm 2.5$ & $1.3-2.2$ & $2.44 \pm 2.7$ & $1.8-3.1$ & $1.15 \pm 2.2$ & $0.5-1.8$ & $<0.05$ \\
\hline VAS L & $1.87 \pm 2.5$ & $1.4-2.3$ & $2.08 \pm 2.5$ & $1.5-2.6$ & $1.8 \pm 2.7$ & $1.0-2.6$ & 0.571 \\
\hline VISA-P R & $84.8 \pm 17$ & $81.6-88$ & $80.8 \pm 18.3$ & $76.7-84.9$ & $88.4 \pm 16.3$ & $83.5-93.2$ & $<0.05$ \\
\hline VISA-P L & $85.3 \pm 19$ & $81.7-88$ & $83.2 \pm 19.1$ & $78.9-87.5$ & $86.3 \pm 19.3$ & $80.6-92.1$ & 0.383 \\
\hline AP5 R & $4.8 \pm 1.2$ & $4.6-5$ & $5.32 \pm 1.2$ & $5.0-5.6$ & $4.05 \pm 0.9$ & $3.8-4.3$ & $<0.001$ \\
\hline AP5 L & $4.75 \pm 1.6$ & $4.4-5.0$ & $5.34 \pm 1.7$ & $4.9-5.7$ & $3.87 \pm 0.9$ & $3.6-4.1$ & $<0.001$ \\
\hline AP10 R & $4.43 \pm 1.1$ & $4.2-4.6$ & $4.9 \pm 1.1$ & $4.6-5.1$ & $3.69 \pm 0.7$ & $3.5-3.9$ & $<0.001$ \\
\hline AP10 L & $4.36 \pm 1.2$ & $4.1-4.6$ & $4.85 \pm 1.3$ & $4.5-5.1$ & $3.62 \pm 0.7$ & $3.4-3.8$ & $<0.001$ \\
\hline
\end{tabular}

Abbreviations: AP5, anteroposterior diameter at 5 mm; AP10, anteroposterior diameter at 10 mm; L, left knee; R, right knee; VAS, visual analog scale; VISA-P, Victorian institute of sport assessment-patella.

that, in the case of the model based on the AP diameter at $5 \mathrm{~mm}$, the years playing suggested statistical significance $(p=0.053)$, showing a certain coherence in the results at $5 \mathrm{~mm}$ and at $10 \mathrm{~mm}$ (-Table 4).

In the case of the VAS score for the left knee (-Table 5), only the AP diameter at $5 \mathrm{~mm}$ and at $10 \mathrm{~mm}$ showed a statistically significant relationship (the greater the AP diameter, the greater the VAS), both on an individual level, as well as adjusted by the remaining variables.

- Tables 6 and 7 show the results obtained by relating the previous variables with the scores on the VISA-P scale. For the right knee, by adjusting the effects using a multiple linear regression model, a significant effect was revealed in the model at $5 \mathrm{~mm}$ and at $10 \mathrm{~mm}$ in the jumping leg (more on the left), and in the AP diameter at $5 \mathrm{~mm}$ and at $10 \mathrm{~mm}$ (lower VISA-P scores with greater AP diameters). The category (lower scores on the highest categories), and the height (a greater score the greater the height) showed differences only in the model at $5 \mathrm{~mm}$. The years played (greater score the greater number of years) displayed differences only in the model at $10 \mathrm{~mm}$, although with a significant tendency in the model at $5 \mathrm{~mm}$. In the case of the left knee, both the AP diameters at $5 \mathrm{~mm}$ and at $10 \mathrm{~mm}$, as well as the category, were significantly associated with the score on the VISA-P scale, finding a lower VISA-P value with a higher category or AP diameter. In the case of the position, this was only significantly associated in the $10 \mathrm{~mm}$ model, although with a significant tendency in the model at $5 \mathrm{~mm}$.

\section{Discussion}

The AP diameter of the tendon in both knees was directly associated with the weight and the BMI, and was greater in men, in line with reports by Lian et al, ${ }^{1}$ by Zwerver et al, ${ }^{2}$ and by Cassel et al, ${ }^{6}$ who identified a greater incidence of patellar tendinopathy in men, as well as observing risk factors, such as weight or training volume. However, it is important to consider that the studies on tendinopathies in women are scarce, and that male teams train for a greater number of hours per week.
The male teams trained more hours per week, both in terms of strength training as well as specific sports training and, furthermore, they presented an average height and BMI that were greater than those of women. For this reason, it is important to consider whether the greater incidence of tendinopathies in men is due to gender differences or whether this is due to the fact that male players are more exposed to these risk factors. In the multiple linear regression models, the effect of gender on the outcome variables of the study was adjusted by these and by other characteristics of the players, while considering the possible interaction effects. Even so, for at least one of the knees, men presented a greater feeling of pain and less functionality. This could mean that, apart from the hours of strength training, volleyball training and the anthropometric characteristics of the players, other variables exist, such as the intensity of play or jumping power, which could explain this difference. Therefore, it would be interesting for future studies to perform a biomechanical analysis of the jump and reception technique for both genders.

The results obtained reveal a direct relationship between the AP diameter of the patellar tendon and the scores obtained on the VAS (adjusting for the remaining study variables), and an indirect relationship with the scores obtained with the VISA-P scale in both tendons whether the diameter was registered at $5 \mathrm{~mm}$ or at $10 \mathrm{~mm}$ distal to the inferior pole of the patella. Therefore, greater tendon diameters are associated with higher scores on the pain scale and with lower scores on the functionality scale. These results coincide with those obtained by Malliaras et $\mathrm{al}^{17}$ and by Zhang et al, ${ }^{16}$ according to whom, subjects with greater pain have a greater tendon diameter. The average AP diameter was $\sim 5 \mathrm{~mm}$ in men and $>4.2$ in women, considering that the criteria proposed by Malliaras et al ${ }^{14}$ was inapplicable, which establishes that a diameter $>4.2 \mathrm{~mm}$ in men is related with patellar tendinopathy. However, the results obtained are in line with those described in the study by Visnes et $\mathrm{al}^{15}$, which reflect that tendons $>5 \mathrm{~mm}$ in men and $>4.2 \mathrm{~mm}$ in women have a greater risk of deriving in tendinopathy.

Regarding the characteristics of play, we were able to confirm that the players with greater pain in the right tendon 
Table 4 Association between the VAS result and the anteroposterior diameter (at $5 \mathrm{~mm}$ and at $10 \mathrm{~mm}$ ) adjusted by the characteristics of play and by the characteristics of the athletes; Right knee

\begin{tabular}{|c|c|c|c|c|c|c|c|c|c|c|c|c|}
\hline \multirow{4}{*}{$\begin{array}{l}\begin{array}{l}\text { VAS right } \\
\text { knee }\end{array} \\
\text { Parameter }\end{array}$} & \multirow{2}{*}{\multicolumn{4}{|c|}{ Non-adjusted effects }} & \multicolumn{8}{|c|}{ Adjusted effects } \\
\hline & & & & & \multicolumn{4}{|l|}{$5 \mathrm{~mm}$} & \multicolumn{4}{|l|}{$10 \mathrm{~mm}$} \\
\hline & \multirow[t]{2}{*}{ B } & \multicolumn{2}{|l|}{$95 \% \mathrm{Cl}$} & \multirow[t]{2}{*}{ p-value } & \multirow[t]{2}{*}{ B } & \multicolumn{2}{|l|}{$95 \% \mathrm{Cl}$} & \multirow[t]{2}{*}{ p-value } & \multirow[t]{2}{*}{ B } & \multicolumn{2}{|l|}{$95 \% \mathrm{Cl}$} & \multirow[t]{2}{*}{ p-value } \\
\hline & & Inferior & Superior & & & Inferior & Superior & & & Inferior & Superior & \\
\hline Age & 0.002 & -0.076 & 0.081 & 0.951 & 0.025 & -0.079 & 0.129 & 0.633 & 0.071 & -0.035 & 0.178 & 0.191 \\
\hline \multicolumn{13}{|l|}{ Gender } \\
\hline Male & 1.264 & 0.341 & 2.187 & 0.007 & 0.574 & -0.823 & 1.972 & 0.421 & 0.711 & -0.745 & 2.167 & 0.338 \\
\hline Female & 0 & . & . & . & 0 & . & $\cdot$ & . & 0 & . & . & . \\
\hline \multicolumn{13}{|c|}{ Player position } \\
\hline Other & 0.022 & -1.080 & 1.123 & 0.969 & -0.052 & -1.067 & 0.963 & 0.920 & 0.279 & -0.790 & 1.348 & 0.609 \\
\hline $\begin{array}{l}\text { Center or } \\
\text { opposite } \\
\text { hitter }\end{array}$ & 0 & . & . & . & 0 & . & . & . & 0 & . & . & . \\
\hline \multicolumn{13}{|l|}{ Jump leg } \\
\hline Other & 1.346 & 0.459 & 2.233 & 0.003 & 1.178 & 0.333 & 2.022 & $0.006^{*}$ & 1.339 & 0.451 & 2.227 & $0.003^{*}$ \\
\hline Left & 0 & . & . & . & 0 & . & . & . & 0 & . & . & . \\
\hline $\begin{array}{l}\text { Type of } \\
\text { court }\end{array}$ & 0.366 & 0.833 & & 0.833 & & & & 0.611 & & & & 0.676 \\
\hline Taraflex & -0.203 & -1.170 & 0.764 & 0.681 & 0.559 & -0.546 & 1.665 & 0.321 & 0.443 & -0.726 & 1.612 & 0.458 \\
\hline Wood & 0.240 & -1.384 & 1.864 & 0.772 & 0.052 & -1.642 & 1.746 & 0.952 & -0.418 & -2.147 & 1.312 & 0.636 \\
\hline Cement & 0 & . & . & . & 0 & . & . & . & 0 & . & . & . \\
\hline Category & & & & 0.300 & & & & 0.281 & & & & 0.662 \\
\hline $\begin{array}{l}\text { Super } \\
\text { league }\end{array}$ & 0.827 & -0.243 & 1.896 & 0.130 & 0.415 & -1.556 & 2.385 & 0.680 & 0.517 & -1.556 & 2.589 & 0.625 \\
\hline $\begin{array}{l}\text { Super } \\
\text { league } 2\end{array}$ & 0.614 & -0.549 & 1.776 & 0.301 & 0.900 & -0.315 & 2.114 & 0.147 & 0.582 & -0.683 & 1.846 & 0.367 \\
\hline $\begin{array}{l}\text { First } \\
\text { division }\end{array}$ & 0 & . & . & . & 0 & . & . & . & 0 & . & . & . \\
\hline AP5 D & 0.723 & 0.364 & 1.082 & 0.000 & 0.797 & 0.369 & 1.225 & $0.000^{*}$ & & & & \\
\hline AP10 D & 0.660 & 0.244 & 1.077 & 0.002 & & & & & 0.648 & 0.139 & 1.156 & $0.013^{*}$ \\
\hline Height & 0.038 & -0.005 & 0.080 & 0.082 & -0.055 & -0.115 & 0.004 & 0.069 & -0.041 & -0.104 & 0.022 & 0.200 \\
\hline BMI & 0.203 & -0.008 & 0.413 & 0.059 & 0.070 & -0.156 & 0.295 & 0.545 & 0.076 & -0.158 & 0.309 & 0.526 \\
\hline $\begin{array}{l}\text { Hours } \\
\text { playing }\end{array}$ & -0.039 & -0.115 & 0.038 & 0.320 & -0.106 & -0.214 & 0.001 & $0.053 "$ & -0.146 & -0.258 & -0.034 & $0.011^{*}$ \\
\hline $\begin{array}{l}\text { Hours } \\
\text { strength }\end{array}$ & 0.173 & -0.069 & 0.415 & 0.161 & 0.010 & -0.289 & 0.309 & 0.945 & -0.038 & -0.352 & 0.276 & 0.814 \\
\hline $\begin{array}{l}\text { Hours } \\
\text { volleyball }\end{array}$ & 0.025 & -0.037 & 0.087 & 0.426 & 0.016 & -0.060 & 0.092 & 0.681 & 0.001 & -0.079 & 0.081 & 0.981 \\
\hline
\end{tabular}

Abbreviations: AP5 D, anteroposterior diameter at $5 \mathrm{~mm}$; AP10 D, anteroposterior diameter at $10 \mathrm{~mm}$; BMI, body mass index; VAS, visual analog scale.

*statistically significant; "tendency to significance.

and who also had a greater tendon diameter were those who mostly jumped with the right leg and had been playing volleyball for the least number of years. On the other hand, those who reported more pain in the left tendon were mainly those who occupied the center and opposite hitter positions, which are front row positions on the court. This is in line with the affirmations by Schafle et $\mathrm{al}^{7}{ }^{7}$ who considered that players facing the net, who require a greater jump potency during hits and blocks, have three times more knee injuries when compared to those who play in the defense line. Regarding the indirect relationship between the score on the pain scale and the number of years playing volleyball, this could be explained due to a learning effect, both on a technical level, for the improved performance of the sports technique, as well as for preparatory and preventive aspects (stretching, awareness of one's limitations, preventive muscle work, among others).

When analyzing the scores on the VISA-P scale, the only association that is significant both in the right knee and in the left knee was with the AP diameter. This assigns significant value to this measurement as being a prognostic factor of loss regarding the functionality in the knee. 
The Relationship between the Anteroposterior Diameter of the Patellar Tendon, Pain and Functionality in Volleyball

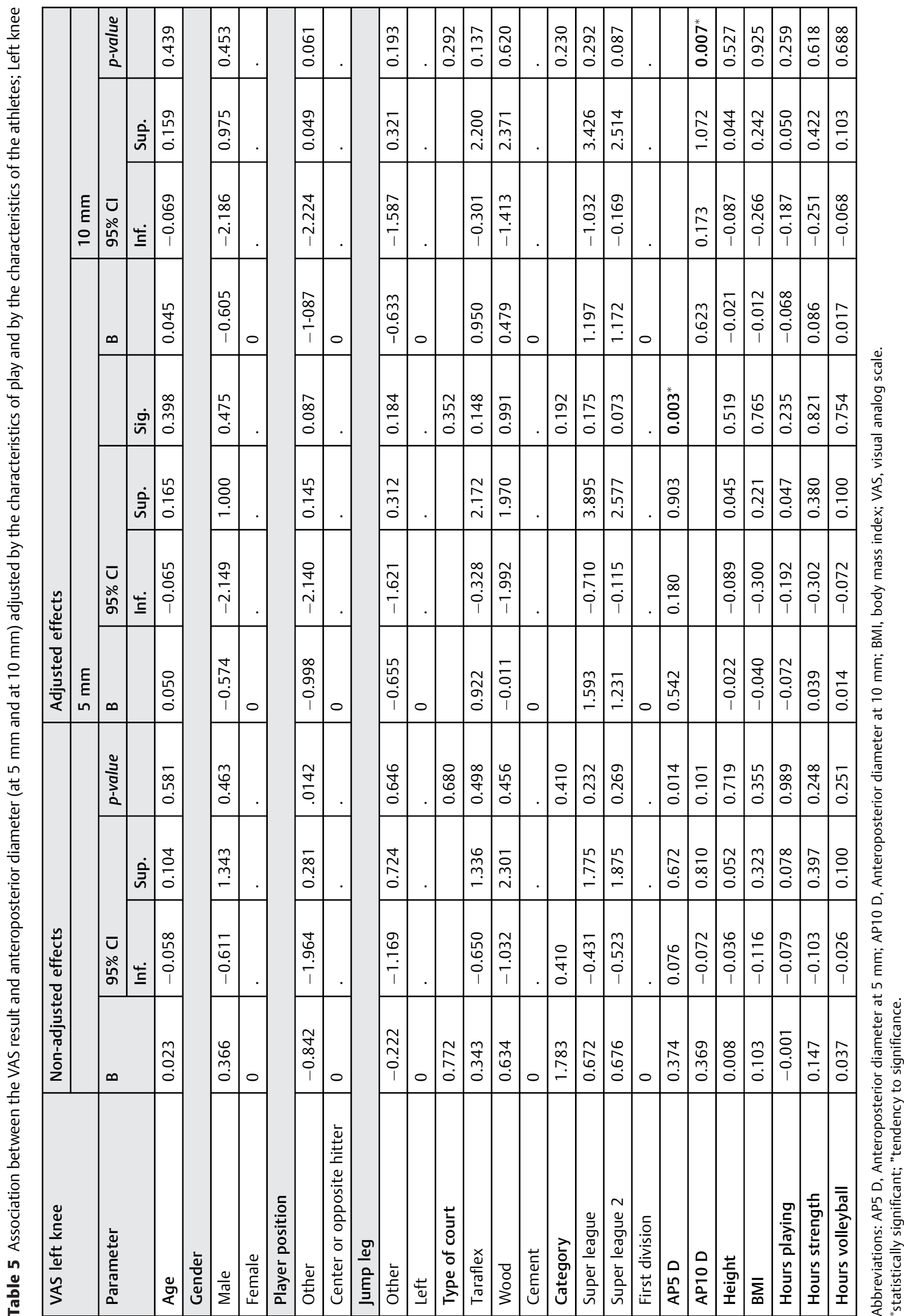




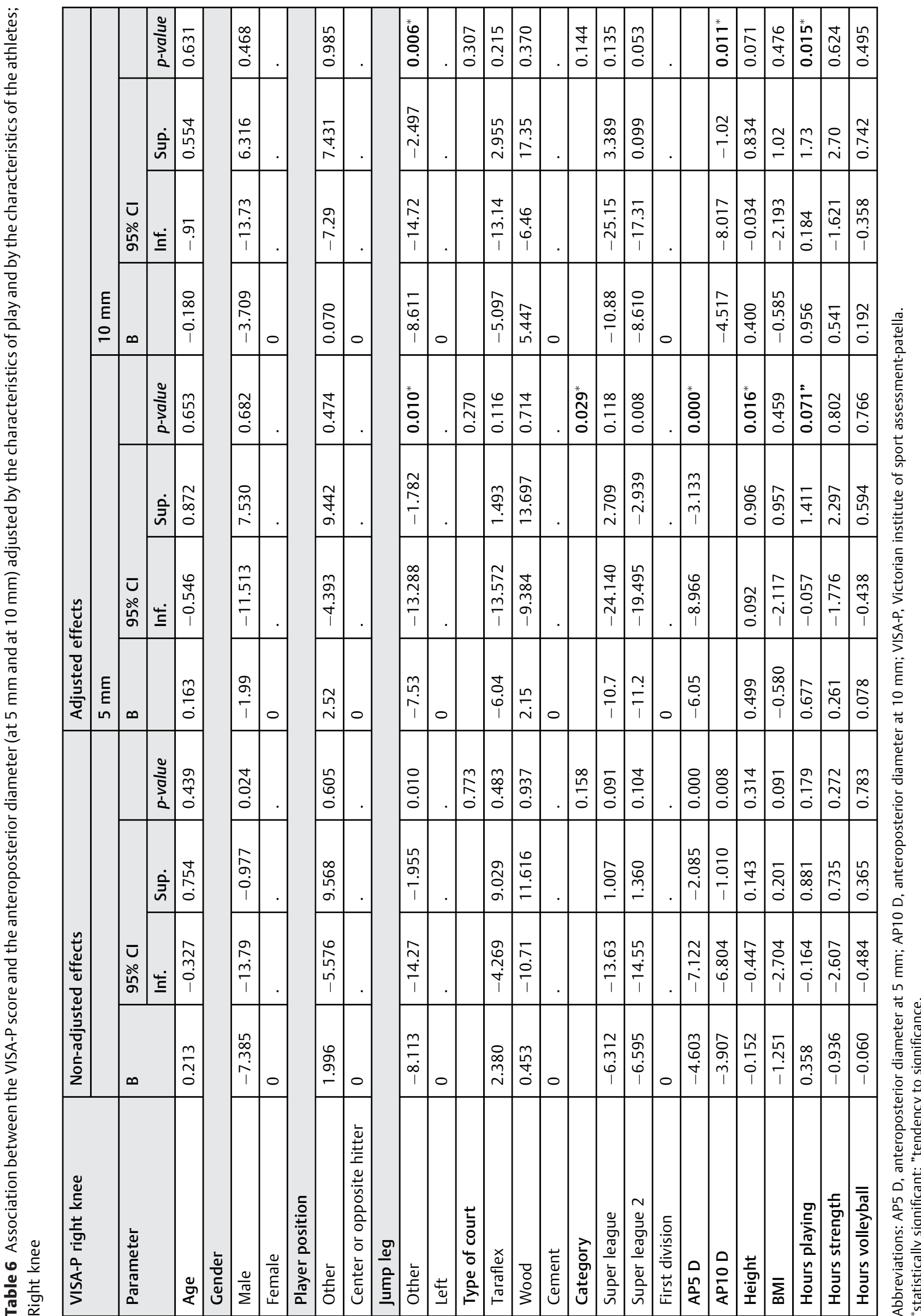


The Relationship between the Anteroposterior Diameter of the Patellar Tendon, Pain and Functionality in Volleyball

Players Calvo Gonell et al.

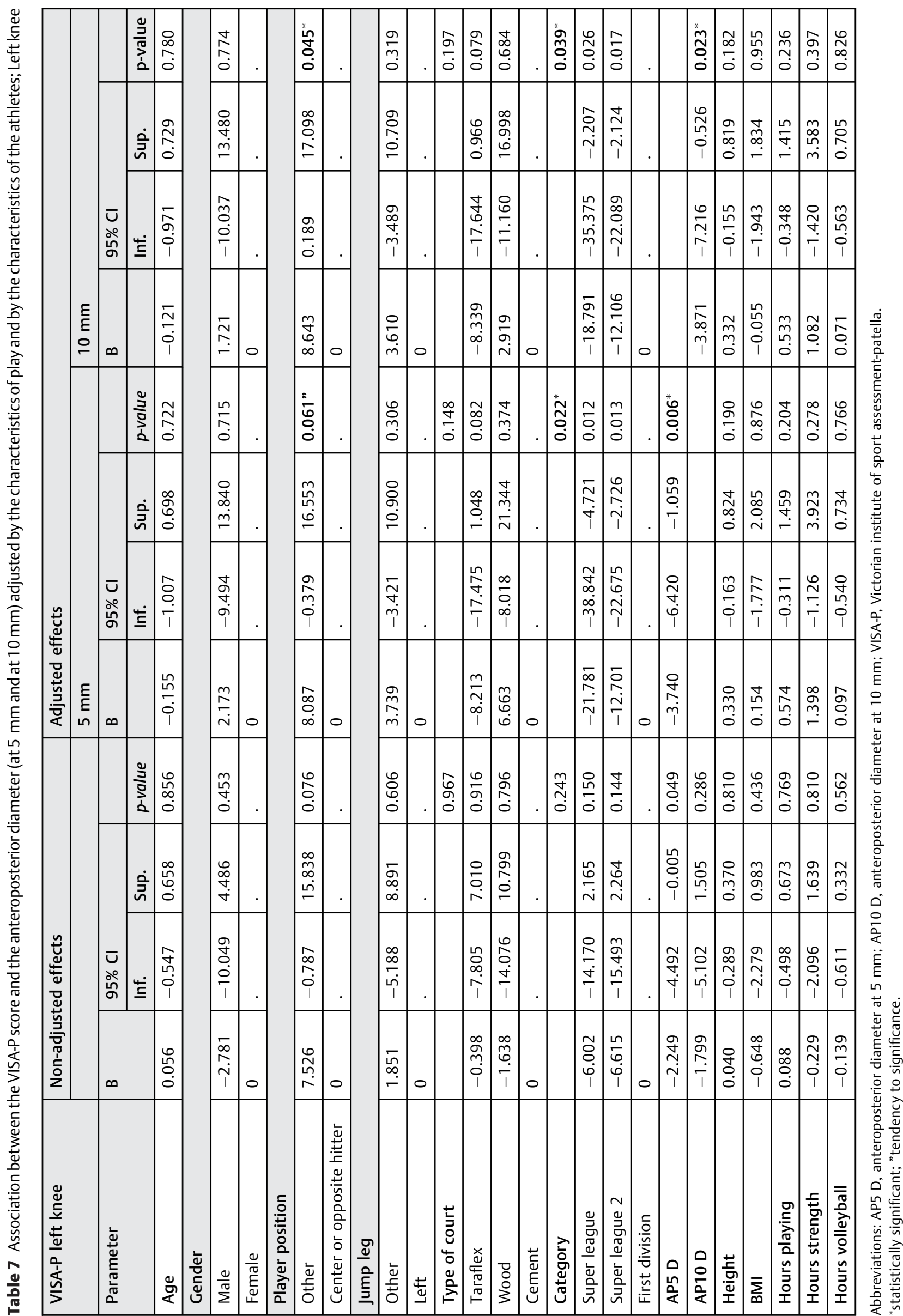




\section{Conclusions}

The measurement of the AP diameter of the patellar tendon may be useful for the prevention of sports injuries in volleyball players, by significantly associating it with a greater sensation of pain and decreased functionality. In future studies, it would be recommendable to include a biomechanical analysis of the jump and reception techniques.

\section{Conflicts of Interest}

The authors have no conflicts of interest to declare.

\section{References}

1 Lian OB, Engebretsen L, Bahr R. Prevalence of jumper's knee among elite athletes from different sports: a cross-sectional study. Am J Sports Med [Internet] 2005;33(04):561-567 Retrieved March 19, 2016

2 Zwerver J, Bredeweg SW, van den Akker-Scheek I. Prevalence of Jumper's knee among nonelite athletes from different sports: a cross-sectional survey. Am J Sports Med [Internet] 2011;39(09): 1984-1988 Retrieved February 7, 2016

3 Ferretti A. Epidemiology of jumper's knee. Sports Med [Internet] 1986;3(04):289-295 Retrieved March 20, 2016

4 Malliaras P, Cook JL, Kent PM. Anthropometric risk factors for patellar tendon injury among volleyball players. Br J Sports Med [Internet] 2007;41(04):259-263, discussion 263 Retrieved February 22, 2016

5 Rubio Gimeno S, Chamorro M. Lesiones en el deporte. Arbor Cienc Pensam Cult. 2000;165(650):203-225

6 Cassel M, Baur H, Hirschmüller A, Carlsohn A, Fröhlich K, Mayer F. Prevalence of Achilles and patellar tendinopathy and their association to intratendinous changes in adolescent athletes. Scand J Med Sci Sports [Internet] 2015;25(03):e310-e318 Retrieved June 24, 2016

7 Schafle MD, Requa RK, Patton WL, Garrick JG. Injuries in the 1987 national amateur volleyball tournament. Am J Sports Med 1990; 18(06):624-631

8 Briner WW Jr, Benjamin HJ. Volleyball injuries: managing acute and overuse disorders. Phys Sportsmed 1999;27(03): 48-60

9 Blazina ME, Kerlan RK, Jobe FW, Carter VS, Carlson GJ. Jumper's knee. Orthop Clin North Am [Internet] 1973;4(03):665-678 Retrieved March 16, 2016
10 Cook JL, Khan KM, Harcourt PR, Grant M, Young DA, Bonar SF; The Victorian Institute of Sport Tendon Study Group. A cross sectional study of 100 athletes with jumper's knee managed conservatively and surgically. Br J Sports Med [Internet] 1997;31(04):332-336 retrieved September 25, 2016

11 Hägglund M, Zwerver J, Ekstrand J. Epidemiology of patellar tendinopathy in elite male soccer players. Am J Sports Med 2011;39(09):1906-1911

12 Carr JC, Hanly S, Griffin J, Gibney R. Sonography of the patellar tendon and adjacent structures in pediatric and adult patients. AJR Am J Roentgenol [Internet] 2001;176(06):1535-1539 Retrieved March 19, 2016

13 Grassi W, Filippucci E, Farina A, Cervini C. Sonographic imaging of tendons. Arthritis Rheum [Internet] 2000;43(05):969-976 Retrieved November 13, 2016

14 Malliaras P, Cook J. Changes in anteroposterior patellar tendon diameter support a continuum of pathological changes. Br J Sports Med 2011;45(13):1048-1051

15 Visnes H, Tegnander A, Bahr R. Ultrasound characteristics of the patellar and quadriceps tendons among young elite athletes. Scand J Med Sci Sports 2015;25(02):205-215

16 Zhang ZJ, Ng GY, Lee WC, Fu SN. Changes in morphological and elastic properties of patellar tendon in athletes with unilateral patellar tendinopathy and their relationships with pain and functional disability. PLoS One [Internet] 2014;9(10):e1083-37 Retrieved March 19, 2016

17 Malliaras P, Purdam C, Maffulli N, Cook J. Temporal sequence of greyscale ultrasound changes and their relationship with neovascularity and pain in the patellar tendon. Br J Sports Med 2010; 44(13):944-947

18 Kulig K, Landel R, Chang Y-J, et al. Patellar tendon morphology in volleyball athletes with and without patellar tendinopathy. Scand J Med Sci Sports 2013;23(02):e81-e88

19 Hernandez-Sanchez S, Hidalgo MD, Gomez A. Cross-cultural adaptation of VISA-P score for patellar tendinopathy in Spanish population. J Orthop Sports Phys Ther [Internet] 2011;41(08): 581-591 Retrieved March 19, 2016

20 Cook JL, Khan KM, Kiss ZS, Griffiths L. Patellar tendinopathy in junior basketball players: a controlled clinical and ultrasonographic study of 268 patellar tendons in players aged $14-18$ years. Scand J Med Sci Sports 2000;10(04):216-220

21 Black J, Cook J, Kiss ZS, Smith M. Intertester reliability of sonography in patellar tendinopathy. J Ultrasound Med [Internet] 2004;23(05):671-675 Retrieved March 16, 2016

22 Skou ST, Aalkjaer JM. Ultrasonographic measurement of patellar tendon thickness-a study of intra- and interobserver reliability. Clin Imaging 2013;37(05):934-937 
Annex 1 For the researchers to complete

Name: Code:

Weight: Age: High: BMI: Years playing: Position:

Months with pain in the knee right left

Jumping leg / knee right left both

Amount of consumption in liters per day Water: Isotonic:

Dedicated time in minutes to stretch at the end of each workout:

If you apply ice on the knee after each workout, how many minutes:

Brand and model of sneakers you train:

Weekly hours of strength training: h

Weekly volleyball specific training hours: h

VAS right:

0 10

VAS left:

0 10

VISA P right:

Anechoic images R:

Neovascularization R:

Diameter A-P R:

IPP R:

ROM dorsiflexion R:
VISA P left:

Anechoic images L:

Neovascularization L:

Diameter A-P I:

IPP L:

ROM dorsiflexion L: 